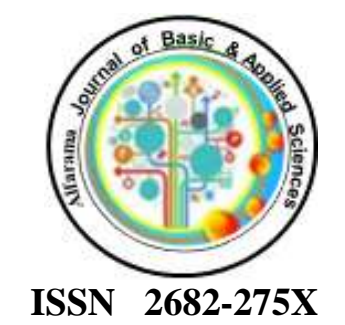

Faculty of Science Port Said University http://sci.psu.edu.eg/en/

DOI: $10.201608 / A J B A S .2019 .19064 .1003$

\title{
ALTERATIONS OF VITAMIN D IN CHRONIC RENAL FAILURE PATIENTS AND ITS RELATION WITH CALCIUM AND PHOSPHORUS LEVELS
}

\author{
Abdel-Aziz. F. Abdel-Aziz ${ }^{1}$, Ayman. E. EL- Agroudy ${ }^{2}$, Mohamed. A. Mahmoud ${ }^{3}$ \\ and Nashwa. A. Mohamed ${ }^{3, *}$ \\ ${ }^{1}$ Department of Chemistry, Faculty of Science, Mansoura University, Mansoura, Egypt \\ ${ }^{2}$ Department of Chemistry, Faculty of Medicine, Mansoura University, Mansoura, Egypt \\ ${ }^{3}$ Department of Chemistry, Faculty of Science, Port Said University, Port Said, Egypt \\ *Corresponding author: nashwanemoo@yahoo.com
}

\begin{abstract}
Endocrine system of vitamin D is central to regulate bone and calcium homeostasis so, alterations lead to disturbances in mineral metabolism. There was increasing risk of death among patients with chronic renal failure (CRF) when there were low in vitamin D and calcium levels. In this study, we evaluated vitamin D in patients with chronic renal failure also, estimated the potential link between vitamin $\mathrm{D}$, serum calcium and phosphorus levels, in order to know if the deficiency of vitamin D can be used as predisposing risk factors and morbidity indicator in hemodialysis patients. Sixy five chronic renal failure patients and 25 healthy volunteers served as a control group were included in our study. Patients with deficiency of vitamin D had a low level of calcium and high level of phosphorus level and alkaline phosphatase activity. In chronic renal failure, there were low significant in vitamin D and calcium levels; while the phosphorous level and alkaline phosphatase activity were significantly high when compared with control group. There was significant negative correlation between level of serum phosphorus, vitamin $\mathrm{D}$ and calcium in chronic renal failure patients. On the other hand there was significant positive correlation between serum calcium and vitamin D levels
\end{abstract}

Keywords

Alkaline phosphatase, chronic renal failure, Vitamin D

\section{INTRODUCTION}

Chronic renal failure increasing prevalence in many developing countries such as Egypt due to many factors as urinary tract infections (8.8\%), diabetes mellitus (15.5\%), obesity (17.7\%), and 
hypertension (31.8\%), so the main risk factors of chronic renal failure are hypertension and diabetes [1] . Mortality is markedly elevated in patients with (CRF). Hemodaylsis (HD) remains the most common technique for treatment of CRF patients [2]. Certain hormones produced by kidney that play an important functions in the body, as an active form of vitamin D (calcitirol or 1, 25 dihydroxy vitamin D) involved to regulate absorption of calcium and phosphorus from foods and promotes its storage in the tissues in the body [3].

Chronic renal failure is associated with multiple metabolic disturbances of calcium, phosphorus and vitamin D [4]. Vitamin D is responsible for enhancing intestinal absorption of calcium and phosphate, low vitamin D is associated with incident hypertension [5],insulin resistance [6], peripheral arterial disease ,cardiovascular disease [7,8] and mortality [9].

\section{EXPERIMENTAL}

This study included 90 subject; 65 patients with mean age $45.2 \pm 14.01$ years they were 39 (60\%) males and 26 (40\%) females. Patients received dialysis treatment at the Urology and Nephrology Center, Mansoura University, after diagnosis of chronic renal failure disease (CRF) by nephrologists; each patient was dialysed 3 times a week, 25 healthy volunteers were collected from the donation blood bank, Mansoura University, with mean age $39.3 \pm 10.2$ years, they were $13(52 \%)$ males and $12(48 \%)$ females. Serum creatinine, uric acid, blood urea nitrogen (BUN) and liver function parameters as serum albumin, total bilirubin, liver enzymes (ALT, AST and ALP) were tested. The control subjects had normal kidney functions, normal level of vitamin D. They were free from any kidney diseases.

\subsection{Collection of blood sample and biochemical analysis}

All samples of patients were collected before the dialysis .One milliliter from $5 \mathrm{ml}$ was collected on ethylenediaaminetetraacetic acid (EDTA) for evaluation of hemoglobin level. The rest of blood (4ml) were collected on free tubes without addition of anticoagulants, were centrifuged at $3000 \mathrm{rpm}$ for 5 minutes to obtain serum and measured vitamin D by using enzyme- linked immunosorbent assay (ELISA) using DRG 25-OH Vitamin D (total) [10] (reference range; 14 to $65 \mathrm{ng} / \mathrm{mL}$ ) and vitamin D (total) standards with their optical density (OD) fig (1).Serum calcium was measured by colorimetric end point (reference range; 8.6 to $10.0 \mathrm{mg} / \mathrm{dl}$ ), in the same way serum phosphorus was determined by colorimetric end point method [11] (reference range; 3.5 to $5 \mathrm{mg} / \mathrm{dl}$ )

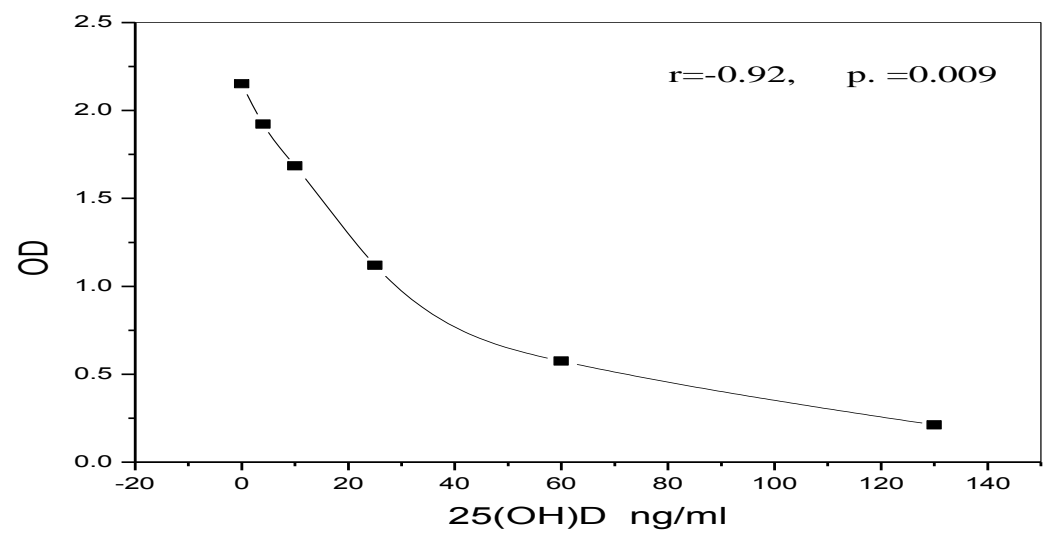

Figure (1): Standard curve of serum vitamin D 


\subsection{Laboratory data}

In The present study, clinical parameters such as creatinine ,blood urea nitrogen (BUN) and uric acid were tested for chronic renal failure (CRF) patients, $(n=65)$, as well as control subjects $(n=25)$. Serum creatinine, blood urea nitrogen and uric acid are commonly used to screen renal disease or to investigate urinary sediment and hypertension; it is also used to monitor renal function after transplantation and in chronic kidney disease. Table (2) shows the levels of creatinine, BUN and uric acid were significantly increased in CRF patients when compared with control subjects $(\mathrm{p}<0.001)$. Serum albumin, total bilirubin, and liver enzymes (alkaline phosphatase, alanine amino transferase, and aspartate amino transferase) are parameters used in the routine investigation of liver functions and used to detect any disturbance in the liver either symptomatic or asymptomatic patients. Sodium and potassium are the two primary electrolytes in the body, working together to maintain fluid balance in the cell, potassium found inside the cell but sodium is the main electrolyte in extracellular fluid.

\subsection{Statistical analysis}

Data were entered and analyzed using: Statistical Package for Social Sciences (SPSS) software (version 25). Data expression: Qualitative data were expressed as count and percent. Data were expressed as mean \pm standard deviation (SD). The CRF patients and control subjects results were performed by chi-square analysis and independent t-test. Correlation between parameters was determined by Pearson's correlation coefficient (r). Statistical significance was determined as $p$ values $\leq 0.05$.

\section{RESULTS AND DISCUSSION}

Patients with chronic renal failure usally have common signs and high symptoms related to the fluid, electrolyte and metabolic-disturbances, anemia, malnutrition, hypertension, bone disease, hormonal and gastrointestinal problems [12]. In CRF patients as the number of functioning nephrons decreases, the failing kidneys are unable to regulate some minerals as phosphorus and calcium. There is a progressive increase in serum phosphorus so, a progressive decrease in calcium levels occur, higher serum of phosphorus concentrations in hemodialysis patients associated with hypocalcaemia [13]. High levels of phosphorus are always an important risk factor for mortality in hemodialysis patients [14].

In several medical conditions, vitamin D has been shown to play an important role in the human body [15]. Insufficiency and deficiency of vitamin D has been high present common for patients throughout all stages of CKD and can for lead to growth of deficits in an earliest the stages [16]. In renal diseases, the ability of renal to convert vitamin D (calcidiol) to 1, 25 vitamin D (calcitirol; active form of vitamin D) decreased and the absorption of calcium form intestine as a consequence decreases (hypocalcaemia) [17]. Several studies have shown that people with CKD are at high risk of deficiency in vitamin D [18, 19, and 20].

As discovered in Table (1), there was no important distinction elderly and body mass index (BMI) in CRF patients when put next with management subjects.Body mass index (BMI) is a person's weight per kilograms $(\mathrm{kg})$ divided by height per $(\mathrm{cm} 2)$. National institutes of health $(\mathrm{NIH})$ now define normal weight, overweight and obesity according to (BMI). The heartbeat force per unit area (SBP) and heartbeat force per unit area (DBP) were considerably higher in CRF patients than up to the mark subjects, (p <0.001). On the opposite hand, level of $\mathrm{Hb}$ was considerably lower in CRF patients as compared to regulate subjects $(\mathrm{P}<0.001)$. 
Table (1): Demographic and clinical data of studied subjects

\begin{tabular}{|c|c|c|c|}
\hline Parameters & $\begin{array}{c}\text { CRF patients }(n=65) \\
(\text { Mean } \pm \text { SD })\end{array}$ & $\begin{array}{c}\text { Control Subjects }(\mathrm{n}=25) \\
(\text { Mean } \pm \text { SD })\end{array}$ & $P$ - value \\
\hline Age(years) & $45.2 \pm 14.01$ & $39.3 \pm 10.2$ & NS \\
\hline BMI $\left(\mathrm{kg} / \mathrm{cm}^{2}\right)$ & $28.6 \pm 4.8$ & $31.0 \pm 5.2$ & NS \\
\hline SBP $(\mathrm{mmHg}) / 24 \mathrm{~h}$ & $158.8 \pm 13.1$ & $122.1 \pm 6.8$ & $<0.001 *$ \\
\hline DBP $(\mathrm{mmHg}) / 24 \mathrm{~h}$ & $96.2 \pm 5.1$ & $78.01 \pm 4.2$ & $<0.001 *$ \\
\hline Hemoglobin (mg /dl) & $8.9 \pm 2.3$ & $13.2 \pm 1.1$ & $<0.001^{*}$ \\
\hline
\end{tabular}

In thist study ,clinical parameters like creatinine ,blood urea nitrogen (BUN) and uric acid were tested for chronic kidney failure (CRF) patient $(n=65)$, and control subjects $(n=25)$. Table (2) shows the levels of creatinine, blood urea nitrogen and uric acid were considerably multiplied in CRF patients when put next with management subjects $(\mathrm{p}<0.001)$. As observed in table (3) the levels of vitamin $\mathrm{D}$, Calcium, sodium and albumin were lower significant in CRF patients than in control subjects, on the other hand the levels of potassium, phosphorus, alkaline phosphatase were highly significant in CRF patients than in control subjects. As shown in table (4) there were significant negative correlation between serum phosphorus, vitamin D and calcium fig $(2,3)$, on the other hand there was significant positive correlation between serum calcium and vitamin D fig (4).

Table (2): Kidney function parameters in chronic renal failure patients and control subjects

\begin{tabular}{|l|c|c|c|}
\hline \multicolumn{1}{|c|}{ Parameter } & $\begin{array}{c}\text { CRF patients }(\mathbf{n}=65) \\
\text { (Mean } \pm \text { SD) }\end{array}$ & $\begin{array}{c}\text { Control Subjects (n=25) } \\
\text { (Mean } \pm \text { SD) }\end{array}$ & P- value \\
\hline Creatinine (mg/dl) & $8.8 \pm 0.3$ & $0.5 \pm 0.1$ & $<0.001^{*}$ \\
\hline BUN $(\mathrm{mg} / \mathrm{dl})$ & $86.6 \pm 7.9$ & $7.4 \pm 0.4$ & $<0.001^{*}$ \\
\hline Uric acid ( mg/dl) & $6.6 \pm 0.2$ & $4.2 \pm 0.3$ & $<0.001^{*}$ \\
\hline
\end{tabular}

*Significant value $(\mathrm{p}<0.05)$.Data were expressed as means. SD: standard deviation. Results were obtained using independent t-test. Blood urea nitrogen (BUN) 
Table (3): Biochemical Features of studied subjects $(n=65)$ with control Variables Subjects $(n=25)$

\begin{tabular}{|l|c|c|c|}
\hline \multicolumn{1}{|c|}{ Parameter } & $\begin{array}{c}\text { CRF patients( n=65) } \\
(\text { Mean } \pm \text { SD) }\end{array}$ & $\begin{array}{c}\text { Control Subjects (n=25) } \\
(\text { Mean } \pm \text { SD) }\end{array}$ & P- value \\
\hline Sodium (mmol/L) & $128.9 \pm 3.3$ & $143.9 \pm 2.1$ & $<0.001^{*}$ \\
\hline Potassium (mmol/L) & $5.4 \pm 0.22$ & $4.13 \pm 0.11$ & $<0.001^{*}$ \\
\hline Calcium (mg/dl) & $8.01 \pm 0.2$ & $10.15 \pm 0.1$ & $<0.001^{*}$ \\
\hline Phosphorus (mg/dl) & $5.4 \pm 0.18$ & $3.2 \pm 0.09$ & $<0.001^{*}$ \\
\hline Vitamin D (ng/ml) & $12.11 \pm 0.2$ & $46.2 \pm 4.6$ & $<0.001^{* *}$ \\
\hline Albumin (g/dl) & $3.26 \pm 0.19$ & $4.55 \pm 0.14$ & $<0.001^{*}$ \\
\hline ALT (U/L) & $18.3 \pm 0.33$ & $17.1 \pm 0.41$ & NS \\
\hline AST (U/L) & $21.1 \pm 0.22$ & $19.9 \pm 0.26$ & NS \\
\hline ALP (U/L) & $139.5 \pm 61.1$ & $81.2 \pm 4.2$ & $<0.001^{*}$ \\
\hline TB (mg/dL) & $0.74 \pm 0.08$ & $0.71 \pm 0.03$ & NS \\
\hline
\end{tabular}

* Significant value $(\mathrm{p}<0.05)$.Data obtained using independent t-test. Alanine aminotransferase (ALT) enzyme. Aspartate aminotransferase (AST) enzyme. Alkaline phosphatase (ALP) enzyme. Total bilirubin (TB).

The present study revealed that there were low significant difference in the levels of serum vitamin D and calcium between CRF patients and controls. On the other hand, there was higher significant difference in the levels of phosphorus than in control group. These results were in accordance with data reported by[21,22] but in contrast to the result of the study taken by [23].These results may explain some features of hypocalcemia and hyperphosphatemia with deficiency of vitamin $\mathrm{D}$ in chronic renal failure (CRF) patients[24]. 


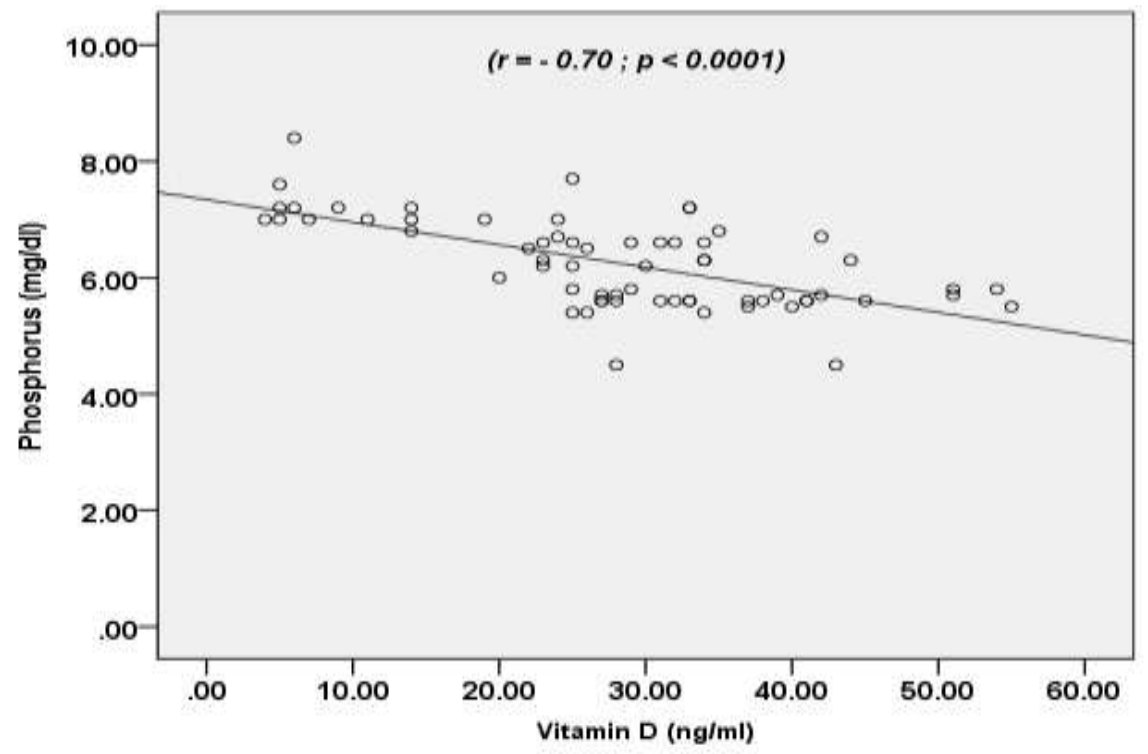

Figure (2): Linear Correlation between serum vitamin D and phosphorus levels in CRF patients.

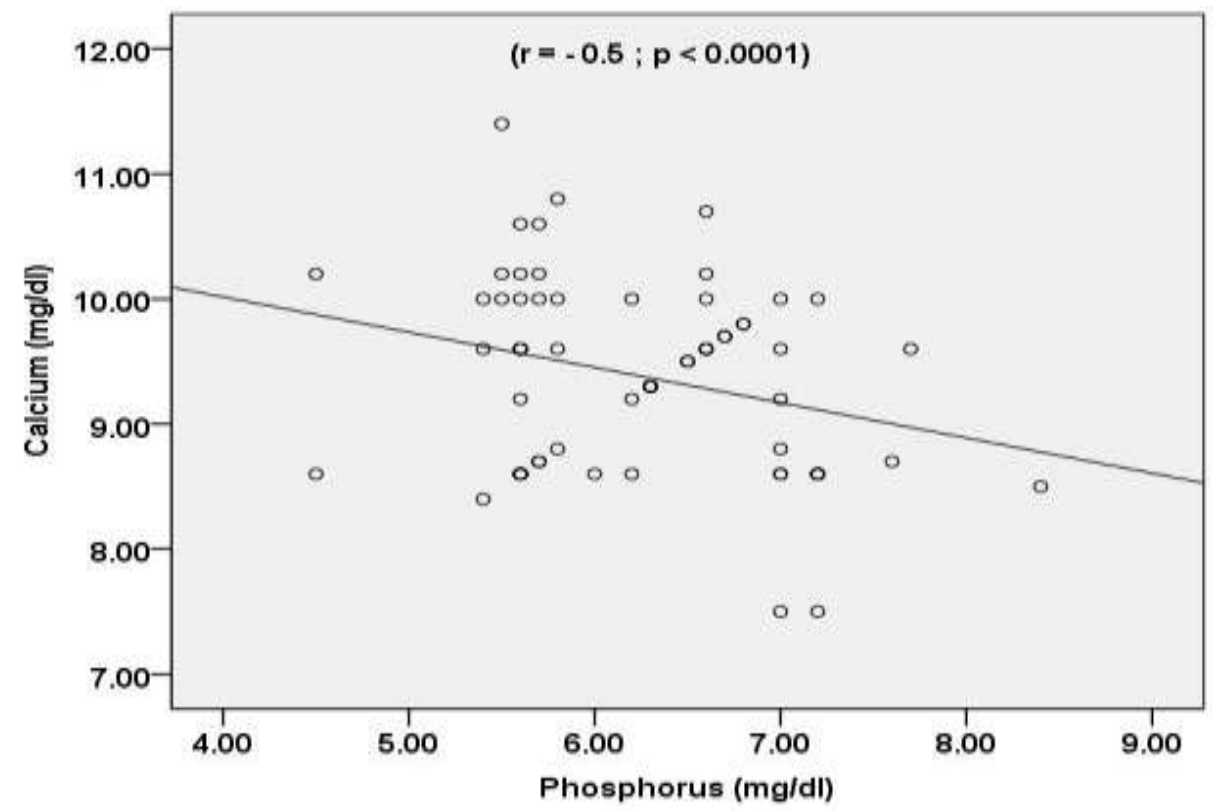

Figure (3): Linear Correlation between serum phosphorus and calcium levels in chronic renal failure patients. 


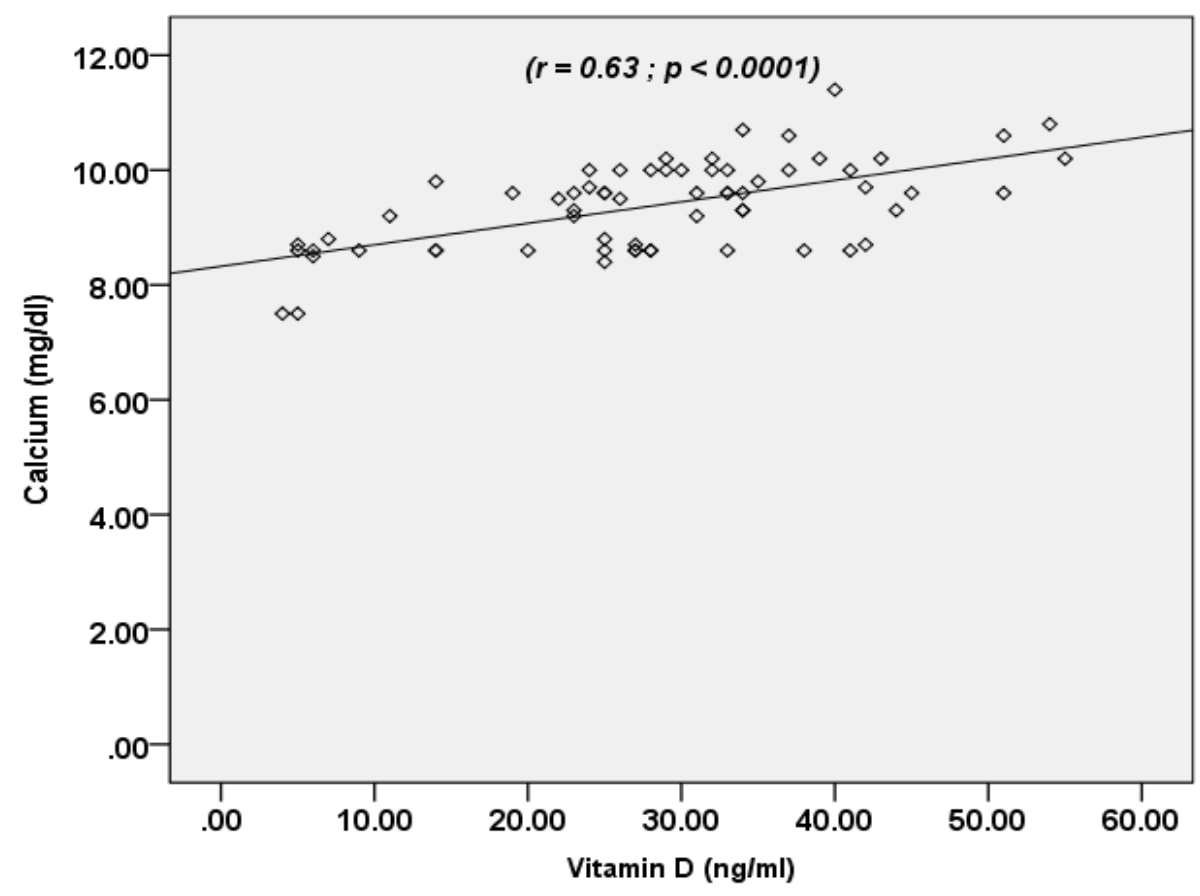

Figure (4): Linear Correlation between serum vitamin D and calcium levels in CRF patients.

In this study, we observed a highly significant inverse correlation between serum levels of phosphorus, vitamin D and calcium levels as in figure (2 and 3), this in accordance with[25,26]..Also, there was positive correlation between serum vitamin D and calcium levels as in figure (4), this result were in contrast to the result of the study taken by [21].

\section{CONCLUSION}

Deficiency of vitamin D in patients with CRF increases with long-term hemodialysis. According to this study, we found that low serum vitamin D associated with low serum calcium and high serum phosphorus levels among CRF patients. This study suggested that they may be used as morbidity indicator and low turnover bone in chronic renal failure patients.

\begin{tabular}{|c|c|}
\hline \multicolumn{2}{|c|}{ List of Abbreviations } \\
\hline Abbreviations & Full name \\
\hline CRF & Chronic Renal Failure \\
\hline HD & Hemodaylsis \\
\hline BMI & Body Mass Index \\
\hline SBP & Systolic Blood Pressure \\
\hline DBP & Diastolic Blood Pressure \\
\hline ALT & Alanine Amino Transferase \\
\hline AST & Aspartate Amino Transferase \\
\hline ALP & Alkaline Phosphatase \\
\hline TB & Total Bilirubin \\
\hline
\end{tabular}




\begin{tabular}{|c|c|}
\hline SPSS & Statistical Package for Social Sciences \\
\hline
\end{tabular}

\section{REFERENCES}

[1] GHONEMY, T. A., FARAG, S. E., SOlIMAN, S. A., El-OKELY, A. \& EL-HENDY, Y. Epidemiology and risk factors of chronic kidney disease in the El-Sharkia Governorate, Egypt. Saudi J Kidney Dis Transpl, 27, 111-7, 2016..

[2] DASHTI-KHAVIDAKI, S., KHALILI, H., VAHEDI, S.-M. \& LESSAN-PEZESHKI, M. Serum zinc concentrations in patients on maintenance hemodialysis and its relationship with anemia, parathyroid hormone concentrations and pruritus severity. Saudi Journal of Kidney Diseases and Transplantation, 21, 641-645, 2010..

[3] KHAN, K. N. M., HARD, G. C. \& ALDEN, C. L. Chapter 47 - Kidney. In: HASCHEK, W. M., ROUSSEAUX, C. G. \& WALLIG, M. A. (eds.) Haschek and Rousseaux's Handbook of Toxicologic Pathology (Third Edition). Boston: Academic Press, 2013.

[4] MARTIN, K. J. \& GONZÁLEZ, E. A. Metabolic Bone Disease in Chronic Kidney Disease. Journal of the American Society of Nephrology, 18, 875-885, 2007.

[5] FORMAN, J. P., GIOVANNUCCI, E., HOLMES, M. D., BISCHOFF-FERRARI, H. A., TWOROGER, S. S., WILLETT, W. C. \& CURHAN, G. C. Plasma 25-hydroxyvitamin D levels and risk of incident hypertension. Hypertension, 49, 1063-9, 2007.

[6] PITTAS, A. G., HARRIS, S. S., STARK, P. C. \& DAWSON-HUGHES, B. The effects of calcium and vitamin D supplementation on blood glucose and markers of inflammation in nondiabetic adults. Diabetes Care, 30, 980-6, 2007.

[7] WANG, T. J., PENCINA, M. J., BOOTH, S. L., JACQUES, P. F., INGELSSON, E., LANIER, K., BENJAMIN, E. J., D'AGOSTINO, R. B., WOLF, M. \& VASAN, R. S. Vitamin D deficiency and risk of cardiovascular disease. Circulation, 117, 503-11, 2008..

[8] GIOVANNUCCI, E., LIU, Y., HOLLIS, B. W. \& RIMM, E. B. 25-hydroxyvitamin D and risk of myocardial infarction in men: a prospective study. Arch Intern Med, 168, 1174-80, 2008.

[9] MElamed, M. L., MUNTNER, P., MiChOS, E. D., URIBARRI, J., WEBER, C., SHARMA, J. \& RAGGI, P. Serum 25-hydroxyvitamin D levels and the prevalence of peripheral arterial disease: results from NHANES 2001 to 2004. Arterioscler Thromb Vasc Biol, 28, 1179-85, 2008.

[10] HOUGHTON,L. A . \& VIETH,R. The case against ergocalciferol (vitamin D2) as avitamin suppplement.Am.j.Nutr;84,694-97, 2006..

[11] TIETZ, N,W., E,D. Clinical Guide to Laboratory Tests,2nd Philadelphia Pa: WB Saunders company:444-447, 1990.

[12] ARNOLD, R., ISSAR, T., KRISHNAN, A. V. \& PUSSELL, B. A. Neurological complications in chronic kidney disease. JRSM cardiovascular disease, 5, 2048004016677687-2048004016677687, 2016..

[13] CHANDRA, P., BINONGO, J. N., ZIEGLER, T. R., SCHLANGER, L. E., WANG, W., SOMEREN, J. T. \& TANGPRICHA, V. Cholecalciferol (vitamin D3) therapy and vitamin D insufficiency in patients with chronic kidney disease: a randomized controlled pilot study. Endocr Pract, 14, 10-7, 2008..

[14] ZATTA, P., DALLA VIA, L. \& DI NOTO, V. Binding studies on aluminum(III)-

[15] albumin interaction. Arch Biochem Biophys, 417, 59-64, 2003.

[16] OGUnKOlade, B. W., BOUCHER, B. J., PRAHL, J. M., BUSTIN, S. A., BURRIN, J. M., NOONAN, K., NORTH, B. V., MANNAN, N., MCDERMOTT, M. F., DELUCA, H. F. \& HITMAN, 
G. A. Vitamin D receptor (VDR) mRNA and VDR protein levels in relation to vitamin D status, insulin secretory capacity, and VDR genotype in Bangladeshi Asians. Diabetes, 51, 2294-300, 2002.

[17] SEEHERUNVONG, W., ABITBOL, C. L., CHANDAR, J., ZILLERUELO, G. \& FREUNDLICH, M. Vitamin D insufficiency and deficiency in children with early chronic kidney disease. J Pediatr, 154, 906-11.e1, 2009..

[18] KARBACH, U. Paracellular calcium transport across the small intestine. J Nutr, 122, 672-7, 1992.

[19] FOURNIER, A., FARDELlONE, P., ACHARD, J. M., GHAZALI, A., PRUNA, A., EL ESPER, N. \& MORINIERE, P. Importance of vitamin D repletion in uraemia. Nephrol Dial Transplant, 14, 819-23, 1999.

[20] MCNERNY, E. M. B. \& NICKOLAS, T. L. Bone Quality in Chronic Kidney Disease: Definitions and Diagnostics. Curr Osteoporos Rep, 15, 207-213, 2017.

[21] ADAME PEREZ, S. I., SENIOR, P. A., FIELD, C. J., JINDAL, K. \& MAGER, D. R. Frailty, HealthRelated Quality of Life, Cognition, Depression, Vitamin D and Health-Care Utilization in an Ambulatory Adult Population With Type 1 or Type 2 Diabetes Mellitus and Chronic Kidney Disease: A Cross-Sectional Analysis. Can J Diabetes, 43, 90-97, 2019..

[22] GHORBAnihaghJO, A., ARGANI, H., SAMADI, N., VAliZADEH, S., HALAJZADEH, J., YOUSEFI, B. \& RASHTCHIZADEH, N. Relationship between vitamin D receptor gene FokI and ApaI polymorphisms and serum levels of fetuin-A, vitamin D, and parathyroid hormone in patients on hemodialysis. Iran J Kidney Dis, 8, 394-400, 2014..

[23] HOLICK, M. F. Vitamin D status: measurement, interpretation, and clinical application. Ann Epidemiol, 19, 73-8, 2009..

[24] LI, J., MOLNAR, M. Z., ZARITSKY, J. J., SIM, J. J., STREJA, E., KOVESDY, C. P., SALUSKY, I. \& KALANTAR-ZADEH, K. Correlates of parathyroid hormone concentration in hemodialysis patients. Nephrology, dialysis, transplantation : official publication of the European Dialysis and Transplant Association - European Renal Association, 28, 1516-1525, 2013..

[25] FRANCA GOIS, P. H., WOlley, M., RANGANATHAN, D. \& SEguRO, A. C. Vitamin D Deficiency in Chronic Kidney Disease: Recent Evidence and Controversies. Int J Environ Res Public Health, 15, 2018.

[26] RESTREPO VALENCIA, C. A. \& AGUIRRE ARANGO, J. V. Vitamin D (25(OH)D) in patients with chronic kidney disease stages 2-5. Colombia medica (Cali, Colombia), 47, 160-166, 2016.

[27] BOSWORTH, C. \& DE BOER, I. H. Impaired vitamin D metabolism in CKD. Seminars in nephrology, 33, 158-168, 2013.. 